\title{
IMPLEMENTASI MANAJEMEN REKAM MEDIS DI RUMAH SAKIT PKU MUHAMMADIYAH YOGYAKARTA
}

\author{
Fahmi Hakam \\ Program Studi Rekam Medis \& Informasi Kesehatan, FKM, Universitas Veteran Bangun \\ Nusantara \\ e-mail : fahmihakam.01@ gmail.com
}

\begin{abstract}
ABSTRAK
Sistem manajemen pelayanan rekam medis dan informasi kesehatan yang baik di rumah sakit akan mampu menciptakan keteraturan dan mutu pelayanan rekam medis yang baik pula, sehingga pasien mendapatkan pelayanan yang cepat, merata dan teratur serta memuaskan. Berdasarkan pengamatan yang telah dilakukan, bahwa kegiatan manajemen rekam medis di PKU Muhammadiyah Yogyakarta sudah berjalan cukup baik, namun ada beberapa kendala terkait proses pencatatan dan pengelolaan data, serta hal-hal teknis lainnya yang berkaitan dengan penyediaan berkas rekam medis. Merupakan jenis penelitian deskriptif dengan pendekatan kualitatif. Dari hasil penelitian di dapatkan bahwa Formulir yang digunakan di RS PKU Muhammadiyah Yogyakarta menggunakan formulir kertas. Formulir rekam medis yang digunakan di RS PKU Muhammadiyah Yogyakarta secara umum meliputi lembar poliklinik, lembar gawat darurat, lembar rawat inap, resume medis, catatan dokter, dan catatan pemberian obat. Perakitan atau penyusunan berkas rekam medis di RS PKU Muhamadiyah sudah berjalan baik dan sesuai dengan peraturan yang berlaku. Coding dan indexing di RS PKU Muhammadiyah Yogyakarta belum sesuai dengan teori karena belum adanya pengkodingan untuk obat-obatan, alat dan radiologi.
\end{abstract}

Kata kunci : Manajemen Rekam Medis, SOP, Formulir Rekam Medis.

\begin{abstract}
The medical record service management system and good health information in the hospital will be able to create good order and quality of medical record services, so that patients get fast, equitable and orderly services. Based on the observations that have been made, that the medical record management activities in PKU Muhammadiyah Yogyakarta have been going quite, but there are some obstacles related to the process of recording and managing data, as well as other technical matters relating to the provision of medical record files. Is a type of descriptive research with a qualitative approach. From the results of the study, it was found that the forms used in PKU Muhammadiyah Yogyakarta Hospital used paper forms. The medical record forms used in PKU Muhammadiyah Yogyakarta Hospital for generally include polyclinic sheets, emergency sheets, inpatient sheets, medical resumes, doctor's notes, and notes on drug administration. Assembling or compiling medical record files at PKU Muhamadiyah Hospital has been running well and in accordance with applicable regulations. Coding and indexing in PKU Muhammadiyah Hospital in Yogyakarta is not in accordance with the theory because there is no coding for drugs, devices and radiology.
\end{abstract}

Keywords : Medical Record Management, SOP, Medical Record Form.

PENDAHULUAN 
Sistem manajemen pelayanan rekam medis dan informasi kesehatan yang baik di rumah sakit akan mampu menciptakan keteraturan dan mutu pelayanan rekam medis yang baik pula, sehingga pasien mendapatkan pelayanan yang cepat, merata dan teratur serta memuaskan. Pengorganisasian rumah sakit didalamnya juga menyangkut pengorganisasian unit rekam medis. Rekam medis merupakan salah satu kunci utama terjadinya pelayanan kesehatan yang baik (Rustiyanto, 2011).

Menurut Permenkes RI No 269/Menkes/Per/III/2008 tentang Rekam Medis pada pasal 1, rekam medis adalah berkas yang berisikan catatan dan dokumen tentang identitas pasien, pemeriksaan, pengobatan, tindakan dan pelayanan lain yang telah diberikan kepada pasien.

Untuk mencapai tujuan rekam medis diperlukan upaya peningkatan mutu rekam medis oleh Unit Kerja Rekam Medis, dimana upaya peningkatan mutu tersebut sangat tergantung dari tersedianya data dan informasi yang jelas, akurat, terpercaya, dan

\section{METODE PENELITIAN}

Merupakan jenis penelitian deskriptif dengan pendekatan kualitatif. Subjek dalam penelitian ini adalah petugas yang bertanggungjawab dalam proses pendaftaran 3 orang, filling 2 orang, koding 1 orang, Analisis dan Pelaporan 1 orang, serta 1 kepala unit rekam medis. Objek penelitian yaitu implementasi kegiatan manajemen rekam medis di PKU Muhammadiyah Yogyakarta. penyajiannya yang tepat waktu. Data dan informasi kesehatan yang tercantum dalam berkas rekam medis sangat berguna bagi manajemen institusi pelayanan kesehatan untuk menilai pelayanannya, apakah bermutu, efisien, dan efektif (Hakam, 2018).

Dalam unit rekam medis di RS PKU Muhammadiyah Yogyakarta terdiri dari beberapa subsistem yaitu, tempat penerimaan pasien (TPP), assembling \& analising, coding \& indexing, dan filing. Agar subsistem dalam unit rekam medis sesuai dengan kebijakan yang telah ditentukan maka diperlukan Standar Prosedur Operasional (SPO) untuk mengatur jalannya sistem pelayanan di RS PKU Muhammadiyah Yogyakarta.

Berdasarkan pengamatan yang telah dilakukan, bahwa kegiatan manajemen rekam medis di PKU Muhammadiyah Yogyakarta sudah berjalan cukup baik, namun ada beberapa kendala terkait proses pencatatan dan pengelolaan data, serta hal-hal teknis lainnya yang berkaitan dengan penyediaan berkas rekam medis

\section{HASIL}

\section{Manajemen Unit Kerja Rekam Medis}

Struktur organisasi merupakan perangkat manajemen yang menggambarkan pembagian tugas, koordinasi dan kewenangan serta fungsi dari setiap jabatan yang ada dalam organisasi. Struktur organisasi unit rekam medis berpedoman pada struktur organisasi rumah sakit yang ditetapkan oleh Badan Pelaksana Harian RS PKU Muhammadiyah Yogyakarta. Adapun struktur organsasi di lingkungan unit rekam medis dapat digambarkan sebagai berikut : 


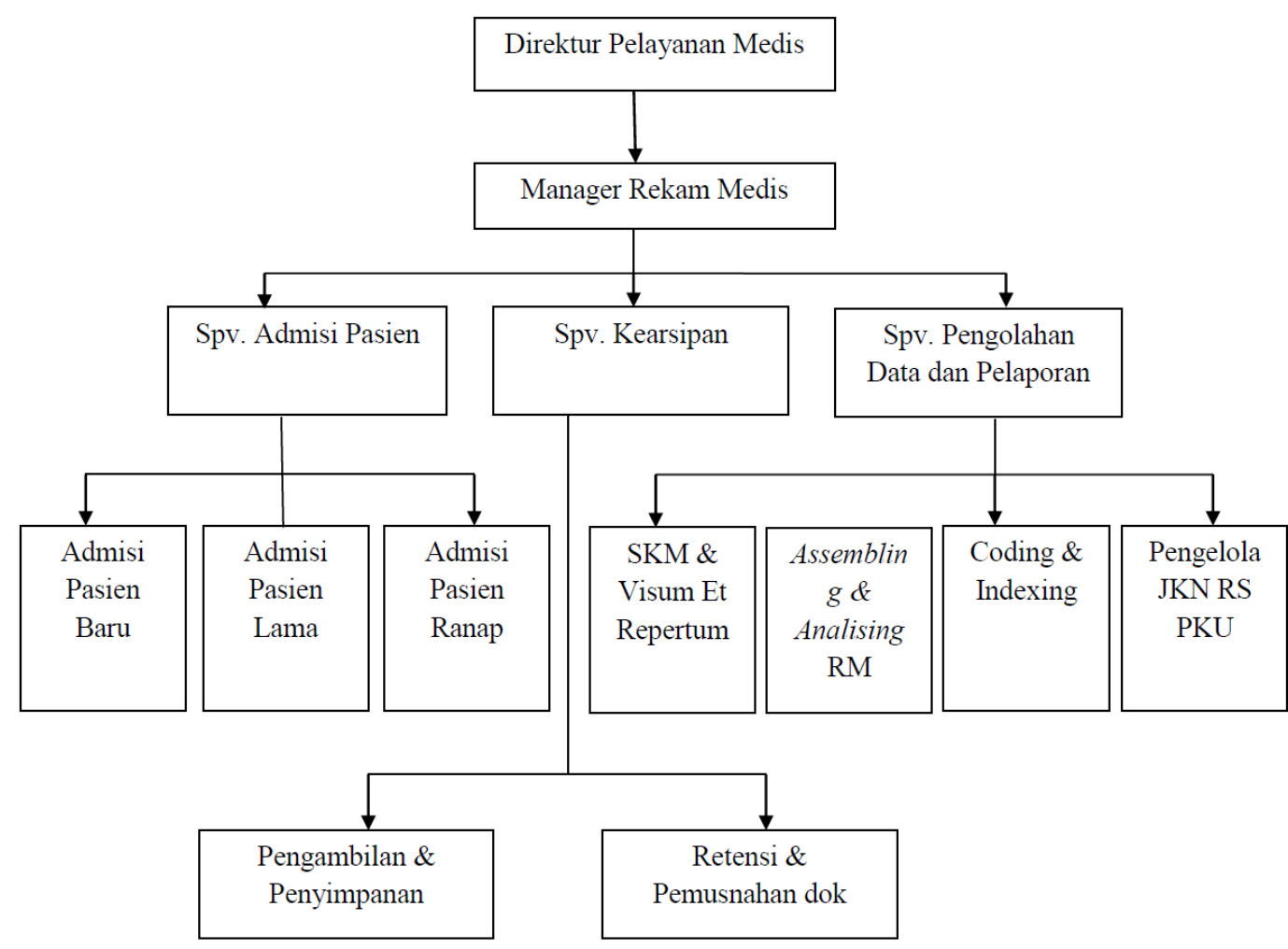

Gambar. Struktur organisasi unit rekam medis RS PKU Muhammadiyah Yogyakarta

Jenis dan Penggunaan Formulir Rekam Medis

Formulir yang digunakan di RS PKU

Muhammadiyah Yogyakarta menggunakan formulir kertas. Adapun formulir rekam medis di RS PKU

Muhammadiyah Yogyakarta berisi tentang :

Tabel. Jenis dan Penggunaan Formulir RM

\begin{tabular}{|c|c|c|}
\hline No & Jenis Formulir & Penggunaan Formulir \\
\hline \multirow[t]{4}{*}{1} & \multirow[t]{4}{*}{ Rawat Jalan } & Lembar poliklinik (RM 01) \\
\hline & & Gawat darurat (RM 02 \\
\hline & & Kebidanan (RM 03) \\
\hline & & Penyakit kandungan (RM 04) \\
\hline \multirow[t]{7}{*}{2} & \multirow[t]{7}{*}{ Administrasi } & Lembar rawat inap (RM 10) \\
\hline & & Lembar hak kuasa (RM 11) \\
\hline & & Persetujuan tindakan medis (RM 12.a) \\
\hline & & Persetujuan tindakan operasi \& pembiusan (RM 12.b) \\
\hline & & Persetujuan tindakan sterilisasi (RM 12.c) \\
\hline & & Surat pernyataan penolakan (RM 12.d) \\
\hline & & Pengambilan keputusan tindakan medis (RM 12.e) \\
\hline \multirow[t]{9}{*}{3} & \multirow[t]{9}{*}{ Rawat Inap } & Pengantar rawat inap (RM 20) \\
\hline & & Catatan pra operasi \& pra anestesi (RM 23.a) \\
\hline & & Catatan operasi (RM 23.b) \\
\hline & & Catatan anestesi (RM 23.c) \\
\hline & & Catatan pemakaian obat dan material operasi (RM 23.d) \\
\hline & & Catatan persalinan (RM 24.a) \\
\hline & & Partogram persalinan (RM 24.b) \\
\hline & & Catatan bayi lahir (RM 25) \\
\hline & & Catatan penyakit kandungan (RM 26) \\
\hline
\end{tabular}




\begin{tabular}{|c|c|c|}
\hline No & Jenis Formulir & Penggunaan Formulir \\
\hline & & Catatan perawatan intensip (RM 27) \\
\hline & & Catatan dokter (RM 30) \\
\hline & & Lembar konsultasi (RM 31) \\
\hline & & Resume medis (RM 33) \\
\hline & & Catatan suhu nadi (RM 34) \\
\hline & & Kontrol istimewa (RM 36) \\
\hline & & Catatan pemberian obat (RM 40) \\
\hline & & Hasil pemeriksaan laboratorium (RM 41) \\
\hline & & Hasil pemeriksaan radio diagnostik (RM 42) \\
\hline & & Hasil pemeriksaan EKG (RM 43) \\
\hline & & Catatan tindakan fisioterapi (RM 44) \\
\hline \multirow[t]{8}{*}{4} & \multirow[t]{8}{*}{ Asuhan Keperawatan } & Rekaman asuhan keperawatan (RM 50) \\
\hline & & Pengkajian awal keperawatan (RM 50.a, b, c) \\
\hline & & Rekam asuhan keperawatan (kebid, anak, bayi) (RM 51) \\
\hline & & f. Pengkajian awal keperawatan (kebid, anak, bayi) (RM 51.a, b) \\
\hline & & Diagnosis keperawatan (RM 52) \\
\hline & & Tindakan keperawatan (RM 53) \\
\hline & & Resume keperawatan (RM 54) \\
\hline & & Perencanaan pulang (RM 55) \\
\hline \multirow[t]{2}{*}{5} & \multirow[t]{2}{*}{ Lain-lain } & Santunan bina ruhani Islam (RM 60) \\
\hline & & Biaya perawatan (RM 69) \\
\hline
\end{tabular}

\section{Coding \& Indexing}

Proses pengkodean dilakukan setelah berkas di assembling dan di analyzing. Kemudian berkas diserahkan ke bagian coding untuk mengkode diagnosis penyakit pasien. Sebelum melakukan pengkodean petugas melihat diagnosis penyakit pasien lalu memberikan kode dengan menggunakan ICD X. Selanjutnya petugas melakukan indexing dengan cara menginput data pasien yang meliputi nomor rekam medis, layanan yang diberikan, dan kode diagnosis penyakit pasien.

\section{Filing}

Dari pengamatan kami sistem penamaan berkas rekam medis di RS PKU Muhammadiyah Yogyakarta ada yang disertai singkatan yang menunjukkan status pasien dibelakang nama pasien contohya : Bayi (By), Anak-anak (An), Laki-laki yang sudah menikah (BP), dll. Namun ada yang tidak mencantumkan singkatan tersebut dibelakang nama pasien.

Sistem penomoran di RS PKU Muhammadiyah Yogyakarta menggunakan Unit Numbering System yaitu setiap pasien yang berkunjung ke fasilitas pelayanan kesehatan akan mendapatkan satu nomor rekam medis (berkas rekam medis) ketika pasien tersebut pertama kali datang dan tercatat sebagai pasien di fasilitas pelayanan kesehatan tersebut. Nomor (berkas) rekam medis ini dapat dipergunakan untuk semua pelayanan kesehatan yang ada di fasilitas pelayanan kesehatan yang bersangkutan, tanpa membedakan pelayanan rawat jalan, rawat darurat, rawat inap atau penunjang medis.

RS PKU Muhammadiyah melakukan penyimpanan berkas rekam medis dengan cara sentraliasasi, yaitu sistem penyimpanan berkas rekam medis dengan cara menyatukan berkas rekam medis pasien rawat jalan, rawat darurat, dan rawat inap kedalam satu folder tempat penyimpanan.

Pelaporan Statistik Rumah Sakit

Laporan Rumah Sakit di RS PKU Muhammadiyah Yogyakarta di peroleh dari kumpulan data kegiatan rumah sakit serta data morbiditas rawat jalan dan rawat inap yang telah tersimpan dengan menggunakan system jaringan. Ada 2 jenis laporan yang di gunakan di RS PKU Muhammadiyah Yogyakarta yaitu :

a. Laporan keluar(extern)

1) RL. 1( data kegiatan rumah sakit)

2) RL. 2a1 ( morbiditas pasien rawat inap)

3) RL. $2 b 1$ ( morbiditas pasien rawat jalan)

4) RL. 2c (data khusus imunisasi rawat inap)

5) RL. 3( inventarisasi rumah sakit)

6) R1.4 (Data ketenagaan rumah sakit)

b.Laporan Kedalam (Intern)

1) Kegiatan Poliklinik dan IGD

2) Kegiatan Lintas Unit Terkait

3) Analisa Data atau Performance RS

4) Visualisai Data (Grafik Indikator Rumah Sakit) 


\section{Metode Retensi dan Pemusnahan Rekam Medis}

\section{Metode Retensi}

Sebelum melakukan pemusnahan berkas rekam medis, petugas harus melakukan pemilahan berkas rekam medis sesuai tahun kunjungan terakhir. Apabila pasien sudah tidak pernah berobat ke RS PKU Muhammadiyah selama 5 tahun maka berkas rekam medis akan di inaktifkan. Apabila selama 5 tahun berikutnya pasien tidak berobat kembali ke RS PKU Muhammadiyah Yogyakarta maka berkas tersebut akan dimusnahkan. RS PKU Muhammadiyah melakukan retensi setiap satu tahun sekali.

\section{Metode Pemusnahan}

Pemusnahan berkas rekam medis artinya suatu proses kegiatan penghancuran secara fisik berkas rekam medis yang telah berakhir fungsi dan nilai gunanya. Penghancuran harus dilaksanakan secara total dengan cara membakar habis, mencacah atau daur ulang sehingga tidak dapat lagi dikenali isi maupun bentuknya.
Tatacara pemusnahan berkas rekam medis di RS PKU Muhammadiyah Yogyakarta

a. Pembentukan tim pemusnahan yang terdiri dari unsur rekam medis dan tata usaha dan dikukuhkan dengan SK Direktur. Tim membuat daftar pertelaan yang meliputi :

1) No. Urut

2) Nomor RM

3) Jangka waktu penyimpanan

4) Diagnosis terakhir

b. Pelaksanaan pemusnahan

1) Dibakar menggunakan incenator atau dibakar biasa

2) Dicacah atau dibuat bubur. Disaksikan pihak ketiga dan tim pemusnah. Sebelum melakukan pemusnahan berkas RM, tim pemusnah harus membuat berita acara pemusnahan yang harus ditandatangani oleh sekretaris serta diketahui direktur RS PKU Muhammadiyah Yogyakarta.

Tabel. Lembar Rekam Medis yang di pertahankan

\begin{tabular}{|c|c|c|}
\hline & Jenis & Lembar Kasus \\
\hline \multirow[t]{7}{*}{1} & Kasus umum & a. Ringkasan/ lembar masuk keluar \\
\hline & & b. Resume \\
\hline & & c. Laporan operasi \\
\hline & & d. Persetujuan/penolakan tindakan medis \\
\hline & & e. Surat pernyatan pulang paksa \\
\hline & & f. Identitas bayi \\
\hline & & $\begin{array}{l}\text { g. Hasil pemeriksaan laboratorium dan radiologi yang penting } \\
\text { (Hasil PA, ct-scan, MRI) }\end{array}$ \\
\hline \multirow[t]{7}{*}{2} & Kasus umum & a. Kasus Kriminal : perkosaan, pembunuhan, dsb \\
\hline & & b. Pasien orang asing \\
\hline & & c. Operasi plastic \\
\hline & & d. Pasien Kancer ( $\mathrm{Ca}$ ) \\
\hline & & e. Orthopedi ( Fracture ) \\
\hline & & f. Penyakit Jiwa \\
\hline & & g. $\quad$ Strelisasi \\
\hline
\end{tabular}

\section{Aspek Hukum Kesehatan yang Berhubungan dengan Rekam Medis}

1. Aspek hukum berkas rekam medis

a. Aspek kepemilikan rekam medis

1) Milik rumah sakit atau tenaga kesehatan :

a) Sebagai penanggung jawab intergritas dan kesinambungan pelayanan.

b) Sebagai tanda bukti rumah sakit terhadap segala upaya dalam penyembuhan pasien.

c) Rumah sakit memegang berkas rekam medis yang asli
2) Milik pasien, pasien mempunyai hak legal maupun moral atas isi rekam medis.

3) Pihak ketiga boleh memiliki (asuransi, pengadilan, dsb) atas izin dari pasien.

b. Aspek yang berkaitan dengan Isi atau Kandungan Rekam Medis (termasuk Catatan Keperawatan) antara lain:

1) Identifikasi (identitas pasien)

2) Autentikasi (Tanggal, nama, jam, tanda tangan) 
3) Resume Medis/ laporan penting ( Anamnesa, Diagnosis, Terapi, Tindakan, dan Catatan Operasi)

4) Pendokumentasian yang baik.

c. Aspek Pemanfaatan Isi atau Kandungan Rekam Medis.

1) Pasien.

2) Pihak ketiga (individu ataupun korporasi).

3) Penegak hukum.

2. Pelaksanaan pemanfaatan aspek hukum yang berkaitan dengan berkas rekam medis

a. Visum Et Repertum

Visum Et Repertum di RS PKU Muhammadiyah Yogyakarta dibuat atas dasar permintaan dari pihak kepolisian atau perorangan yang menjadi korban sebagai alat bukti. Secara hukum keterangan tersebut wajib dibuat, yang pada umumnya terdiri dari :

1) Keterangan tentang fakta-fakta yang ditemukan pada korban

2) Kesimpulan dokter atas fakta-fakta yang didapat pada saat pertama kali memeriksa korban.

Prosedur pembuatan Visum Et Repertum yang adadi RS PKU Muhammadiyah Yogyakarta :

1) Rumah sakit mendapatkan permintaan atau surat permohonan visum et repertum dari kepolisian yang kemudian diproses di instalasi rekam medis.

2) Menanyakan keperluan pembuatan visum et repertum untuk menentukan jenis visum et repertum yang akan dibuat.

3) Pihak rumah sakit atau bagian rekam medis mencarikan data pasien yang melakukan permintaan visum et repertum dan pencarian berkas rekam medis pasien

4) Apabila pasien belum diperiksa maka pasien akan melakukan pemeriksaan dulu oleh dokter.

5) Sebelum dilakukan pembuatan dan penyerahan visum et repertum surat permohonan visum et repertum dan data pasien sementara akan diajukan kepada direktur untuk perijinan pebuatan visum tersebut.

6) Setelah mendapatkan ijin, bagian rekam medis akan memberikan berkas dan surat visum et repertum kepada dokter yang merawat. Untuk pengisian data yang relevan/sesuai dengan hasil pemeriksaan yang dilakukan dokter serta tanda tangan dokter.
7) Hasil visum et repertum yang sudah jadi kemudian diserahkan ke bagian tata usaha untuk dibuatkan surat pengantar.

8) Pengambilan visum et repertum dengan membawa tanda terima pengambilan, nota pembayaran, dan surat pernyataan hak kuasa pelepasan informasi medis pasien.

b. Informed consent

Lembar persetujuan yang ada di rumah sakit PKU Muhammadiyah yaitu meliputi persetujuan tindakan medis, persetujuan tindakan operasi dan pembiusan, persetujuan sterilisasi, surat pernyataan penolakan, pengambilan keputusan tindakan medis.

c. Surat Keterangan Madis (SKM)

Surat keterangan medis adalah surat yang menyatakan pengobatan pasien selama dirawat di RS PKU Muhammadiyah Yogyakarta yang diperlukan untuk kepentingan exsternal rumah sakit, serta untuk memenuhi kebutuhan korespondensi pasien dan menjamin terciptanya tertib adiministrasi.

\section{PEMBAHASAN \\ Manajemen Rekam Medis}

Assembling adalah proses pengurutan atau perakitan berkas rekam medis dan sebagai peneliti kelengkapan isi berkas rekam medis yang telah diisi oleh bagian Unit Rawat Jalan, Unit Rawat Darurat dan Unit Rawat Inap sebelum dilakukan pengkodingan dan disimpan kembali ke bagian filing. Perakitan formulirformulir dalam berkas rekam medis di RS PKU Muhammadiyah Yogyakarta dilakukan berdasarkan urutan nomor formulir rekam medis

Assembling dalam pelayanan rekam medis berperan sebagai perakit formulir rekam medis, penelitian isi data rekam medis, pengendalian berkas rekam medis tidak lengkap, pengendalian penggunaan nomor rekam medis dan formulir rekam medis (SPO RS PKU Muhammadiyah Yogyakarta, 2010). Dari hasil pengamatan kami, perakitan atau penyusunan berkas rekam medis di RS PKU Muhamadiyah sudah sesuai dengan SPO RS PKU Muhammadiyah Yogyakarta tahun 2010.

\section{Jenis dan Penggunaan Formulir Rekam Medis}

Formulir yang digunakan di RS PKU Muhammadiyah Yogyakarta menggunakan formulir kertas. Formulir rekam medis yang digunakan di RS PKU Muhammadiyah Yogyakarta untuk URJ, UGD, dan URI secara umum meliputi lembar poliklinik, lembar gawat darurat, lembar rawat inap, resume medis, catatan dokter, dan catatan pemberian obat.

Menurut Peraturan Menteri Kesehatan Republik Indonesia nomor 269/MENKES/III/2008 data-data yang harus dimasukkan dalam Medical 
Record dibedakan untuk pasien yang diperiksa di unit rawat jalan, rawat inap dan gawat darurat.

Dari hasil pengamatan kami, jenis fomulir yang ada di RS PKU Muhammadiyah Yogyakarta sudah sesuai dengan teori menurut Peraturan Menteri Kesehatan Republik Indonesia nomor 269/MENKES/III/2008.

\section{Coding dan indexing}

Pengkodingan penyakit di RS PKU Muhammadiyah Yogyakarta dilakukan dengan menggunakan ICD-X. Disamping kode penyakit di RS PKU Muhammadiyah Yogyakarta juga melakukan coding tindakan dokter dengan menggunakan ICD 9 CM. Selanjutnya petugas melakukan indexing dengan cara menginput data pasien yang meliputi nomor rekam medis, layanan yang diberikan, dan kode diagnosis penyakit pasien.

Menurut Citra Budi (2011) Coding adalah pemberian penetapan kode dengan menggunakan huruf atau angka atau kombinasi huruf dalam angka yang mewakili komponen data. Fungsi pengkodean rekam medis bertanggungjawab terhadap penemuan dan penulisan kode penyakit, dan operasi yang tertulis pada berkas rekam medis berdasarkan kode yang telah ditetapakan pada ICD-X dan ICOPIM atau ICD 9 CM.

\section{Filing}

Dari pengamatan kami sistem penamaan berkas rekam medis di RS PKU Muhammadiyah Yogyakarta ada yang disertai singkatan yang menunjukkan status pasien dibelakang nama pasien.

Menurut Rustiyanto (2011), penulisan nama pasien diikuti singkatan yang menunjukkan status pasien. Singkatan ini bisa dituliskan didepan nama atau dibelakang nama pasien, pada dasarnya difasilitas pelayanan kesehatan tersebut sebaiknya konsisten penulisannya. Dari hasil pengamatan kami, sistem penamaan di RS PKU Muhammadiyah Yogyakarta belum sesuai dengan teori. Karena masih sering di temukan berkas rekam medis dalam penulisan namanya masih ada yang belum di sertai singakatan yang menunjukkan status pasien.

Sistem penomoran di RS PKU Muhammadiyah Yogyakarta menggunakan Unit Numbering System yaitu setiap pasien yang berkunjung ke fasilitas pelayanan kesehatan akan mendapatkan satu nomor rekam medis (berkas rekam medis) ketika pasien tersebut pertama kali datang dan tercatat sebagai pasien di fasilitas pelayanan kesehatan tersebut.

Menurut Citra Budi (2011), sistem penomoran dalam pelayanan rekam medis yaitu tata cara penulisan nomor yang diberikan kepada pasien yang datang berobat sebagai bagian dari identitas pribadi pasien yang bersangkutan. Sistem penomoran dengan Unit Numbering System yaitu setiap pasien yang berkunjung ke fasilitas pelayanan kesehatan akan mendapatkan satu nomor rekam medis (berkas rekam medis) ketika pasien tersebut pertama kali datang dan tercatat sebagai pasien di fasilitas pelayanan kesehatan tersebut.

\section{Pelaporan}

Di RS PKU Muhammadiyah Yogyakarta data rekam medis yang masuk ke instalasi rekam medis diolah menjadi informasi yang disajikan dalam pelaporan guna pengambilan keputusan manajemen di rumah sakit dan manajemen kesehatan Daerah Tingkat II, Daerah Tingkat I, dan Nasional. Hal tersebut sudah seseuai dengan PERMENKES RI No. 1171/MENKES/PERVI/2011.

\section{Retensi dan Pemusnahan Rekam Medis}

Sebelum melakukan pemusnahan berkas rekam medis, petugas harus melakukan pemilahan berkas rekam medis sesuai tahun kunjungan terakhir. Apabila pasien sudah tidak pernah berobat ke RS PKU Muhammadiyah selama 5 tahun maka berkas rekam medis akan di inaktifkan. Apabila selama 5 tahun berikutnya pasien tidak berobat kembali ke RS PKU Muhammadiyah Yogyakarta maka berkas tersebut akan dimusnahkan.

Menurut surat edaran Dirjen Pelayanan Medik Nomor HK.00.06.1.5.01160 tertanggal 21 Maret tentang Petunjuk teknis Pengadaan Formulir Rekam Medis Dasar dan Pemusnahan Arsip Rekam Medis di Rumah Sakit, untuk pertama kalinya sebelum melakukan proses retensi harus terlebih dulu ditetapkan jadwal retensi arsip rekam medis, secara umum berkas rekam medis akan diretensi setelah 5 tahun dari kunjungan terakhir pasien.

Dari hasil pengamatan kami, retensi yang dilakukan di RS Muhammadiyah Yogyakarta suadah sesuai dengan surat edaran Dirjen Pelayanan Medik Nomor HK.00.06.1.5.01160 tertanggal 21 Maret.

Pemusnahan berkas rekam medis di RS PKU Muhammadiyah Yogyakarta dengan cara dicacah atau dibuat bubur. Disaksikan pihak ketiga dan tim pemusnah. Sebelum melakukan pemusnahan berkas RM, tim pemusnah harus membuat berita acara pemusnahan yang harus ditandatangani oleh sekretaris serta diketahui direktur RS PKU Muhammadiyah Yogyakarta.

\section{SIMPULAN}

1. Perakitan atau penyusunan berkas rekam medis di RS PKU Muhamadiyah sudah berjalan baik dan sesuai dengan peraturan yang berlaku.

2. Coding dan indexing di RS PKU Muhammadiyah Yogyakarta belum sesuai dengan teori karena belum adanya pengkodingan untuk obat-obatan, alat dan radiologi. 
3. Sistem penamaan di RS PKU Muhammadiyah Yogyakarta belum sesuai dengan teori karena masih sering di temukan berkas rekam medis dalam penulisan namanya masih ada yang belum di sertai singakatan yang menunjungkan status pasien.

4. Sistem penjajaran yang digunakan di RS PKU Muhammadiyah Yogyakarta adalah Terminal Digit Filing.

5. Sistem penomoran yang digunakan di RS PKU Muhammadiyah Yogyakarta adalah Unit Numbering System sudah sesuai dengan teori.

6. Retensi di RS PKU Muhammadiyah Yogyakarta di lakukan setelah 5 tahun kunjungan terakhir pasien. Sebelum di lakukan retensi berkas yang masih mengandung nilai guna akan di simpan, sedangkan berkas yang tidak memiliki nilai guna akan di simpan di ruang inaktif.

7. Pemusnahan berkas rekam medis dilakukan dengan cara daur ulang.

8. Fomulir rekam medis yang ada di RS PKU Muhammadiyah Yogyakarta sudah lengkap dan penggunaanya sesuai dengan syarat dan ketentuan rumah sakit.

9. Aspek hukum kesehatan yang berhubungan dengan rekam medis di RS PKU Muhammadiyah Yogyakarta sudah melaksanakan peraturan sebagai penyedia pelayanan kesehatan yaitu berkas tidak diperbolehkan keluar dari rumah sakit tanpa melalui prosedur yang ada dan kerahasiaan terhadap isi dari berkas rekam medis setiap pasien terjamin.

\section{DAFTAR PUSTAKA}

1. Citra Budi, Savitri. 2011. Manajemen Unit Kerja Rekam Medis. Yogyakarta : Quantum Sinergis Media.

2. Hakam, Fahmi. 2018. Analisis Penyediaan Rekam Medis Pasien Rawat Jalan Berdasarkan Standar Operasional Prosedur (SOP) Di Puskesmas X. Volume 1 No 1. Jurnal Manajemen Informasi dan Administrasi Kesehatan.

3. Hakam, Fahmi. 2018. Pelatihan Manajemen Rekam Medis Sesuai Dengan Standar Pedoman Penyelenggaraan Dan Prosedur Rekam Medis di Puskesmas Kecamatan Weru Kabupaten Sukoharjo. Volume 1 No 2. Jurnal Manajemen Informasi dan Administrasi Kesehatan.

4. Hatta, Gemala R. 2014. Pedoman Manajemen Informasi Kesehatan disarana pelayanan kesehatan. Jakarta: UIP
5. Hozizah, 2014. Kumpulan Peraturan Perundangan Rekam Medis dan Informasi Kesehatan (Manajemen Informasi Kesehatan). Yogyakarta: Aptirmik Press.

6. Kementrian Kesehatan Republik Indonesia, 2014. Permenkes RI Nomor 75 Tahun 2014, Indonesia.

7. Kementrian Kesehatan RI, 2008. Permenkes No 269 Tahun 2008 Tentang Rekam Medis, Republik Indonesia.

8. Rustiyanto, Ery. 2015. Etika Profesi dan Hukum Kesehatan dalam Manajemen Rekam Medis dan Informasi Kesehatan. Yogyakarta : PI Press.

9. Rustiyanto, 2011. Manajemen Filing Dokumen Rekam Medis Dan Informasi Kesehatan. Yogyakarta: Politeknik Kesehatan Permata Indonesia.

10. S Utami, AT Susilani, Hakam. 2016. Hubungan Tingkat Pengetahuan Tentang Rekam Medis Dengan Kelengkapan Pengisian Catatan Keperawatan Pada Instalasi Rawat Inap Di Rumah Sakit At-Turots Al Islamy Sleman. Jurnal Permata Indonesia. Volume, 07, No 01, Mei 2016.

11. Team penyusun SPO.2010. Standar Prosedur Operasional Rekam Medis RS PKU Muhammadiyah Yogyakarta. Yogyakarta : RS PKU Muhammadiyah Yogyakarta.

12. WHO. 2010. International Statictical Classification of Disease and Related Health Problem Tenth Revision. 